\title{
ECONOMICS
}

\section{ASSESSMENTS OF A. C. PIGOU'S FELLOWSHIP THESES}

by

Michael McLure

Business School

The University of Western Australia

DISCUSSION PAPER 10.22 


\title{
ASSESSMENTS OF A. C. PIGOU'S FELLOWSHIP THESES
}

\author{
by \\ Michael McLure* \\ Business School \\ The University of Western Australia
}

DISCUSSION PAPER 10.22

\begin{abstract}
This study reports on the light that documents stored in the Archive Centre at King's College Cambridge shed on A. C. Pigou's fellowship theses. Particular consideration is given to Walter Raleigh's and Brooke Foss Westcott's assessments of Pigou's first, and unsuccessful, fellowship thesis on Robert Browning as a Religious Teacher and to Alfred Marshall's and Herbert Foxwell's assessments of Pigou's second, and successful, fellowship thesis on The Causes and Effects of Change in the Relative Values of Agricultural Produce in the United Kingdom during the last Fifty Years. The principal findings of the study are that: Pigou's first thesis is more important to his subsequent and famous studies on wealth and welfare than is generally appreciated; and the assessors' diverse reactions to his second thesis largely reflect their different views on the scope for economic theory to be used by scholars to shed light on economic history.
\end{abstract}

\footnotetext{
* I would like to thank Patricia McGuire, Archivist, and Elizabeth Ennion-Smith and Tracy Wilkinson, Assistant Archivists, at the King's College Archive Centre in Cambridge, for their assistance and advice. I would also like to thank Nahid Aslanbeigui, Gerhard Michael Ambrosi, Roger Backhouse, Peter Groenewegen and Geoff Harcourt for their comments on earlier drafts of this paper, which was first presented at the annual conference of the History of Economic Thought Society of Australia, convened at the University of Sydney between 7 and 9 July 2010, and again at the $42^{\text {nd }}$ UK History of Economic Thought Conference, convened at Kingston University between 16 and 17 September 2010. The paper has also been revised in light of comments made by participants during these conferences.
} 


\section{Assessments of A. C. Pigou's Fellowship Theses}

\section{Introduction}

Arthur Cecil Pigou submitted theses to the King's College fellowship competitions on two occasions. The first, Robert Browning as a Religious Teacher, was submitted in late 1900 as part of the 1901 fellowship round and was assessed by Walter Alexander Raleigh and Brooke Foss Westcott. It was unsuccessful. The second, The Causes and Effects of Change in the Relative Values of Agricultural Produce in the United Kingdom during the last Fifty Years, was submitted in late 1901 as part of the 1902 fellowship round and was assessed by Alfred Marshall and Herbert Foxwell. This second thesis submission was successful, culminating in Pigou being formally elected as a fellow of King's College in 1902. This study reports on the light that archival documents held at King's College Cambridge shed on A. C. Pigou's emerging interest in the economics of wealth and welfare in his formative years at Cambridge up to his election as a fellow of that College.

The study commences with some illustrations of Pigou's growing interest in economics as a student from his letters to Oscar Browning. The relevant extracts are quoted in Section 2 and set in the context of Pigou's broad intellectual interests and the related academic activities he pursued at Cambridge. Pigou's thesis on the poetry of Robert Browning is discussed in Section 3. Attention is drawn to the assessors' concern with Pigou's attempt to identify the philosophical content that underlies the general body of Browning's poetry. It is suggested that Pigou was, among other things, drawn to Browning's poetry by the insights it might provide into what is for the good of the individual and the broader question of what is good for society: the same basic problem that occupied Pigou when he was subsequently writing his more famous studies on the relationship between wealth and welfare. His next fellowship thesis, dealing with the recent history of agricultural commodity values, is examined in Section 4. It is found that the main significance of this thesis is the opportunity it afforded Pigou to investigate, and demonstrate, how Alfred Marshall's approach to the analysis of supply and demand could be applied to isolate the cause of major movements in relative real prices and quantities over a fifty year period. The differing assessments of this thesis partly reflect Foxwell's and Marshall's differing positions on the scope for applying economic theory to reveal insights into concrete economic events that have taken place over time. Marshall also overstates the academic qualities of the thesis, which was partly a consequence of his high regard for Pigou as a thoughtful and caring scholar, which would have marked him as a potentially worthy contributor to King's College and to Cambridge more generally. Foxwell, in contrast, held his personal dislike for Pigou in check when assessing the thesis, but a bias remained that was associated with his strong dislike for economic history being written with too much regard for economic theory.

The conclusions of this study are presented in Section 5. In recognition of Pigou's discussion of 'welfare' in terms of 'states of consciousness' vis-à-vis material wealth, it is argued that his first fellowship thesis on Robert Browning's poetry is not as far removed from his subsequent economic studies of wealth and welfare as it may appear to be prima facie. The writing style of that thesis, with more emphasis placed on a careful focus on detail than on highlighting major themes, also extended to his early writing on welfare issues. In contrast, his second thesis, which is concerned with a specific economic subject, reveals comparatively little of what was at the heart of his subsequent and 'seminal' contributions to welfare theory. Rather, that thesis represented an application of Marshallian equilibrium theory, which served to increase Pigou's appreciation of the explanatory power of that body of theory. One consequence of these two theses, and the relationship between Pigou and Foxwell during that time, was that Marshall came to appreciate that Pigou, and not Foxwell, was more likely to develop economics along the line that he wished it to follow. Indeed, Marshall's well known support 
for Pigou ahead of Foxwell as his successor to the Cambridge Chair in Political Economy in 1908 appears to have had its origin in the period when Pigou was writing his fellowship theses.

\section{Pigou as a Young Scholar at Cambridge}

Pigou entered residence at King's College in autumn 1896, received an undergraduate scholarship in 1898 and, in the following year, successfully obtained a First in the undivided Historical Tripos, which was founded in 1873 by John Seeley. Oscar Browning, who tutored Pigou during this period (Aslanbeigui 1997, p. 301), has reported that the Historical Tripos was founded to train statesmen and not historians:

“[Seeley’s] opinion was, that in order to be effective it should not be a Tripos of historical erudition on research so much as a Political Tripos, a machinery by which men could be trained for learning, reasoning, and perhaps acting in politics; that is, in public affairs connected with the welfare of the state."

(Browning 1910, p. 234).

Seeley's objective for the Historical Tripos was enthusiastically endorsed by Oscar Browning, thereby providing some indication of the general exposure of the young Pigou to ideas taught at Cambridge. In 1899, however, he commenced Part II of the Moral Sciences Tripos, where he read Ethics, Political Philosophy and Economics, being placed in the First Class for this Tripos in the following year (Saltmarsh and Wilkinson 1960, p.4).

From 1900 the Historical Tripos was divided into two parts, ${ }^{1}$ with the indirect but most travelled path to economics at Cambridge being simplified by allowing students to take Part II of the Moral Sciences on completion of Part I of the Historical Tripos. Edwin Gray (1903, p. 493) actually christened this as the 'devious route' by which the goal of becoming an economists was 'approximately obtained' prior to the introduction of the Economics Tripos at Cambridge University in 1903 by Marshall. But in the case of Pigou, his move from the undivided Historical Tripos to Part II of the Moral Sciences Tripos was anything but 'devious', as the possibility of becoming an economist would not have figured large in his mind when he 'came up' to Cambridge on a 'Minor Scholarship' in 'History and Modern Languages'. Indeed, Saltmarsh and Wilkinson (1960, p.4) have emphasised that his 'interests were uncommonly wide'.

It was for his non-economic writings that Pigou first received recognition at Cambridge. In 1899 he won the Chancellor's Medal for English Verse for his poem Alfred the Great and in 1900 he won the Burney Prize for his essay on Robert Browning as a Religious Teacher. The Burney Prize was awarded for an essay "on some moral or metaphysical subject, on the Existence, Nature, and Attributes of God, or on the Truth and Evidence of the Christian Religion” (Cambridge University 1901, p. 613). It was not until 1901, a year after completing Part II of the Moral Sciences Tripos, that his work in economics was to receive acclaim when his dissertation on The Causes and Effects of Change in the Relative Values of Agricultural Produce in the United Kingdom during the last Fifty Years was awarded the Cobden Prize.

Pigou's interest in 'literature, poetry, philosophy and politics' was motivated by a similar drive to that which motivated his interest in economics: a desire to investigate and reflect on what is 'good' for individuals and society, with ethics considered vis-à-vis to feelings, thought and action. For example, in his poem Alfred the Great, the good of society is marked by movement away from

\footnotetext{
${ }^{1}$ I am indebted to Nahid Aslanbeigui for advising me that the Historical Tripos was undivided until 1900.
} 
'soulless greed', as facilitated by inspired leaders for whom truth and reason provide insight into the heartfelt sentiments of men.

I pray to heaven some voices more clear than mine
May lead this people far from the black slough
Of soulless greed, into more generous paths
Onwards and upwards, following Truth's bright star
And reason's light, and the diviner gleam
That dwells a mystery in the hearts of men. ${ }^{2}$

His second award winning work, Robert Browning as a Religious Teacher, considered the works of a poet, though it was not presented from a strictly theological or literary perspective. Rather, in that study Pigou attempted to establish the general system of ethical thought that united Browning's body of poetry and to identify deviations from that system. While the subject matter was poetry, the substance of the study was again concerned with what is good and why it is good, which he subjected to philosophical assessment.

While at Cambridge Pigou was also active in the Political Society at King's College. This Society was founded in 1876 by Oscar Browning. Each year it consisted of around twelve members for the purpose of promoting the scientific study of political questions, with meetings held once a week to discuss an essay prepared by one of the Society’s members (Browning 1910, pp. 235-236). ${ }^{3}$ Later, Browning (1910, p. 242) was to proudly write that from the Society's inception its membership was, on the whole, a 'very distinguished set of men', which included nine subsequent professors with Pigou amongst them. Also, interest in the ethical and political dimensions to social matters was likely to have influenced Pigou's decision to participate in the debating activities of the Cambridge Union. Indeed, he quickly gained a reputation as an orator following his early contribution to the debate on 'Puritanism' (Kadish 1989, p. 192) and was elected secretary, and then vice-president, of the Union in 1899 and president in the following year. His participation in Union debates also extended beyond ethical and political issues, some of which involved the participation of Oscar Browning himself, ${ }^{4}$ and even included economic matters such as the question of free trade.

During 1897 and 1899, Pigou was in frequent correspondence with Oscar Browning. Fortunately, these letters provide some glimpses of the emergence of Pigou's growing interest in economic issues, although his hand writing is often completely illegible, so much so that a degree of uncertainty must be acknowledged over the accuracy with which the author has deciphered Pigou's letters. ${ }^{5}$ In general, Pigou's letters to Browning reveal that his introduction to economics was self motivated but undertaken somewhat begrudgingly - an example where the effort in reading 'dull' books is expended for the purposes of 'improving' oneself. In the September vacation period of an unspecified year, he reported on his first encounter with Marshall's Principles:

\footnotetext{
2 The last six lines of Pigou's Alfred the Great 1899 (cited in Saltmarsh and Wilkinson 1960, p. 5). In his obituary entry for Pigou, Harry Johnson (1960, p.151) even argued that "the last few lines of this ode reflect the idealism which, under the inspiration of Alfred Marshall, led him on to the study of economics."

${ }^{3}$ No member was expected to write more than one essay per term.

${ }^{4}$ While Pigou's ethical and philosophical positions tended to be humanitarian and liberal, he came to oppose Oscar Browning's 1901 motion to the Union that "the only hope for efficient social reform lies in the return of the Liberal party to power" (Kadish 1989, p.192).

${ }^{5}$ According to Saltmarsh and Wilkinson (1960, p15): "His [Pigou's] hand writing was notorious, and could only be interpreted by an expert at Miss Pate's typewriting establishment. Once he wrote a telegram, 'Expect me 5 o.c. Pigou”, and the message arrived 'Export me 500 pigeons'”. In his letter to Saltmarsh of 19 February 1960, Donald Corrie even reported that "I have draws of his [Pigou's] letters which, having now lost the knack, I find very hard to decipher." (Corrie, 1960).
} 
"I've not been entirely slack the whole vac: of books that are dull and improving I've read Hallam's Constitutional History and Marshall's Political Economy / not nearly as bad as Hallam”.

A.C. Pigou (1897-1899), September 23.

It appears that Pigou was, at the time, preparing himself for the study in the Moral Sciences Tripos, although as yet there was no sign of a serious commitment to the study of economics. Consequently, the letter was probably written in September 1897 or September 1898. However, Pigou's (apparently) subsequent letters to Browning reveal his growing interest in economics, starting with an announcement of his commitment to studying economics followed by subsequent revelations of a growing seriousness in his attitude towards the study of economics and ethics.

“I’m going to do Pol. Econ and Economic History here”.

Pigou, (1897-1899) Sunday. ${ }^{6}$

"Inflicted [with] a sprained ankle almost as soon as I got home; result, long sojourning on a sofa and dutiful study of economics. I've done quite a lot of work, often getting up at the barbarous hour of seven to begin”.

Pigou (1897-1899), September 22. ${ }^{7}$

"I write to you from this outlandish spot, ${ }^{8}$ as a place of solitude to which I have come to work - hard work at Ethics and Economics for a fortnight or so.”

Pigou (1897-1899), Wednesday 2 August 1899.

It appears that Pigou came to quickly appreciate that cultivating a deep understanding of economics would enhance his capacity for extensive reflection on the good of society, the concern that is explicitly evident from his ethical and philosophical reflections and implicitly evident from his active participation in the Political Society and the Union, even when that meant challenging the ideas of his early mentor Oscar Browning. ${ }^{9}$ Consequently, the main motivating factor that drew Pigou to literature, poetry, philosophy and politics also appears to have been at play when he decided to study economics and welfare.

Between obtaining his fellowship at Kings in 1902 and succeeding Marshall to the Chair in Political Economy at Cambridge in 1908, Pigou's efforts were primarily, but not exclusively, directed

\footnotetext{
${ }^{6}$ The month and year are not stated by Pigou, but the letter is annotated in pencil with the years 1897-99.

${ }^{7}$ The year is not stated by Pigou, but the letter is annotated in pencil with the years 1897-99.

${ }^{8}$ Hotel de France, Brittany

${ }^{9}$ One consequence of Pigou's maturing and more assertive reflections on economic and social issues, raised either through the Political Society and the Union in 1899-1900, was a change in his personal rapport with Oscar Browning, which effectively moved from that of a special student-master relationship to something approaching that of a peer-peer relationship. Indeed, Browning's feelings appear to have been hurt by the challenge (which such a transition almost inevitably brings), as the following letter from Pigou to Browning suggests:
}

"What you say about my paper to the Political Society rather surprises me. Perhaps it was a bad paper, and you certainly disagreed with it, but surely there was nothing in it that you could regard as a grievance. Nor did it ever occur to me that you would look upon my action in reading your letter to the Union in the way you do, it was an official letter beginning dear Mr Vice-President, and surely, as such, public property. I never for a moment thought that you regarded it as private; had I done so, and I am sorry that I did not, I should hesitate to read it without your permission. As to the rest of my speech, though I cannot admit that it deserves either the general epithet or particular strictures you place on it, I regret that anything I may have said or done should have caused you unnecessary pain, and should be grieved to appear ungrateful for your many kindnesses to me”. Pigou (18991900), April 12. 
towards a series of formal and theoretically oriented papers published in the Economic Journal (1902b, 1903, 1904a, 1904b, 1907a) and the book Protective and Preferential Import Duties (1906a). These studies were prepared concurrently with formal reflections on philosophy, most notably in his collection The Problems of Theism (1908), which, among other things, examined the 'general nature of reality', concerning methodological implications for the social sciences, and the 'problem of good'; as well as specific ethical studies on the 'ethics of the Gospels' and the 'ethics of Nietzsche'. Furthermore, in the same period, Pigou was writing reflective articles on the relationship between economics and politics (1902a, 1906b) and on the relationship between economics, ethics and evolution (1907b). This was also a period in which his practical interest in public policy, labour and the lot of the working classes came to the fore through works like Principles and Methods of Industrial Peace (1905), a published book based on his 1903 essay for which he was awarded the Adam Smith Prize, and 'Protection and the Working Classes' (1906c).

The main significance of the above range of works - be they poetic, ethical or economic - for Pigou's subsequent economic studies is that they collectively provided the foundation upon which he could develop his study of the good of society that emerged in his classic Wealth and Welfare (Pigou 1912), which was substantially revised in 1920 and published in four subsequent editions under a new title: the Economics of Welfare (Pigou 1935).

\section{Assessments of Pigou's Unsuccessful Fellowship Thesis: Robert Browning as a Religious Teacher}

Perhaps the most striking feature of Pigou's experience as a university student is his repeated success at winning Cambridge prizes: the Chancellor's medal for verse in 1899; the Burney Prize "on some moral or metaphysical subject” in 1900, the Cobden prize in 1901 and the Adam Smith Prize in 1903 (for the best essay on any subject of the writers choice). In a curious turn of events, however, his first major academic setback came when his Burney Prize winning essay was submitted as his fellowship thesis in 1901, and was unsuccessful. Perhaps more curious is his choice of thesis topic for his fellowship submission. In the 1901-02 academic year, Pigou had been appointed by Marshall to lecture on his general economic course. Therefore, one may have expected that Pigou would have submitted a fellowship thesis on an economic topic. Moreover, when concern was raised over his choice of thesis topic, Pigou himself insisted that the topic was entirely appropriate. In an undated letter to Oscar Browning, he noted that:

"I only proposed to send in a thing on Browning because I was trying to write one for another purpose. I never thought I'd have any real chance of a fellowship this year in any case ... All the same, I'm surprised at the doubt in accepting Browning as a subject. Surely it comes under the Moral Sciences Tripos, as the main part of religious teaching is simply a mixture of Green's Ethics ${ }^{10}$ and sceptical metaphysics.”

Pigou (circa 1900-1901)

Unsuccessful fellowship theses are not stored at the College archives. Fortunately though, a condition of the Burney Prize is that the winning essay be published, although the published book and

\footnotetext{
${ }^{10}$ T. H. Green was a fellow of Balliol College Oxford and holder of the 'White's Chair of Moral Philosophy' at Oxford University from 1778 until his death in 1882. He was the leading representative of the 'British idealists' and espoused an ethical theory in which: the ultimate goal of human action is self realization achieved with the aid of interpersonal associations; 'good' is conceptualized as 'perfection'; and the 'common good' is associated with the common pursuit of self realization, or perfection, by all members of a society (Shionoya 2010, p. 99).
} 
the fellowship thesis are not one and the same, as the published version had been revised following "criticisms of friends and further reflection" (Pigou 1901, p. vii). The foreword to the published book suggests another oddity: it reveals that Pigou, a resident of King's College, submitted his first fellowship thesis without input from fellows or residents of that College. He acknowledged Mr R. Somerville of Harrow School, for guidance, expresses appreciation to Dr Peile and Mr C. F. G. Masterman of Christ's College, and indicated that his thanks were chiefly due to his friend Mr J. R. P. Schater of Emmanuel College (Pigou 1901. p. x), but no one from King's is acknowledged.

In this thesis Pigou did not differentiate between Browning's religion and his philosophy. As such, he interpreted Browning as 'religious teacher' in the widest possible sense so that he could pursue his main objective of identifying the relations between various philosophical and theological issues "to bring out the relations between them, and to unite them in some kind of system" (Pigou 1901, pp vii-viii). He saw two possible methods of achieving that end: comparison of Browning's poems against some external standard; or comparison of Browning's poems with the general internal philosophical system developed within Browning's work. He rejected the first method, because "it was impossible, however, for me to claim the right either to propound or to postulate any theory of the Universe” (Pigou 1901, pp ix) and adopted the second, leading him to criticize inconsistencies in particular poems relative to the unified ethical propositions that underlie and bond Browning's poetry in general.

If the introduction and conclusion are set aside, the thesis essay is structured in eight chapters concerning Browning's concept of: deity, Christianity, optimism, immortality, God's end for man, progress, the illusory character of evil, and ethics. One major theme that Pigou explores is the notion of continuity in the face of religious uncertainty, where progress from the imperfect to the perfect spans the period of life and extends beyond death. In that context, evil, which Pigou interprets Browning as presenting as an illusory creation, co-exists with goodness, and, to the extent that man chooses between good and evil in reaction to his 'voice of conscience', evil may actually motivate goodness. As such, considerations are undertaken as an iterative process over a long period of time, one's ethics, and the associated spiritual progress, are learned and developed from experience. Man's actions are undertaken in the face of uncertainty and ethical complexity, so it takes a considerable period of time for a person to work towards realising God's end for man: to attain a state where the real image of man and his own perception of himself are one and the same. In that state, the actions of man are in conformity with his conscience.

In his essay, Pigou argued that when Browning's work is taken as a whole, "few poets can be said to have revealed themselves so completely" (Pigou 1901, p. 7). This provides some justification for his initial confidence in the method adopted, with general ethical foundations identifiable and deviations from those foundations revealed. However, by the time that his Burney essay was being readied for publication, Pigou had lost confidence in the effectiveness of that approach because he came to appreciate that the evolving and ever changing poetic moods in Browning's work were so great that no clear underlying system of philosophical thought was revealed. On realising this, he came to the judgement that the work should not be published, but he was obliged to do so under the terms of the Burney Prize. In his words, critical evaluation of the type he undertook in his study:

“... presupposes the existence of a definite system of thought underlying the whole of his poetry, and it is only upon this assumption that charges of inconsistency can fairly be urged. A growing conviction that his moods varied greatly at different times, not merely oscillating about a fixed and constant body of thought, but transforming the whole character of his outlook upon the world and making a unified philosophy impossible for him, ... were it not for the obligation imposed upon the successful candidate for the Burney Prize, I should hesitate long before undertaking to publish it”.

(Pigou 1901, p. ix) 
The referees for Pigou's first fellowship thesis were Dr B. F. Westcott, the Bishop of Durham, and Walter Alexander Raleigh, the then Regius Professor of English Language and Literature at the University of Glasgow. Both had firm links to King's College: Westcott had been appointed to the Regius Professorship of Divinity at Cambridge in 1870, was elected professorial fellow at King's in 1883, appointed Bishop of Durham in 1890 and was a correspondent of Alfred Marshall (Whitaker 1996); and Raleigh had studied at Cambridge and was a resident at King's. Of course, it is highly unlikely that the referees' reports would have been shown to Pigou, but some feedback (without attribution) may have been informally drawn from the referees' reports. This may be the case because Pigou comments above from the preface to the published book echoes some of the criticisms that the Bishop of Durham raised in his report.

"I have done my best to form a judgement on the essay on 'Browning as a religious teacher' which you kindly placed in my hands, but find it very hard to say anything which will be of use to the Electors. ... The writer, if I may express what I feel in another way, has considered Browning rather as a 'philosophical' or 'theological' than as a 'religious' teacher. He has discussed his treatment of certain fundamental opinions and not of life as lived by men. For my own part however highly I rate all that Browning says on any question, I cannot take him seriously as a philosopher. He says by the way much on points of philosophical speculation but he always deals with them as a poet! And his greatness as a religious teacher is seen, I think, in his criticism and interpretations of life, and not in his exposition of doctrine.”

(Westcott 1901)

Walter Raleigh made a similar point concerning the prominence of doctrine, but from a different perspective: instead of maintaining the rigid discipline necessary to discuss, and support, his propositions with textual evidence, Raleigh wanted to see Pigou reveal the originality of thought that it appears he would have been capable of, if only he had broken free from the rigid framework that he imposed on himself.

"The writer is, plainly, well acquainted with Browning's works, and has clearly expounded all the ideas to which Browning gives most frequent and most emphatic expression. ...some of the least poetic of his writings are brought most into evidence. And the essayist's care to support his conclusions by plentiful evidence gives him the air at times of being entangled in his machinery. Some of his remarks in passing are good, and I could not help wishing, in reading his essay, that he would cut himself loose from his authority, and give himself a better and freer opportunity.”

(Raleigh 1901)

Indeed, when the simple expository, or non-critical, part of the essay is considered with respect to the philosophical content of the poet, Raleigh considered the outcome insignificant.

"The weakest part of the essay is to be found I think at the end, where the statement of the "content" of Browning's ethical teaching furnishes a kind of anti-climax, and the concluding criticisms, - perhaps because they were not part of the original scheme - are perfunctory and meagre.”

(Raleigh 1901) 
As such, the essay is almost 'condemned with faint praise', but only 'almost'. In the final paragraph of the report generally, and especially the final sentence, Raleigh was very careful to point out that, notwithstanding the narrow and constrained scope of the essay, it still bore 'positive testimony' to the candidate’s unfulfilled potential:

"I believe he is capable of more original work than this. ...

On the whole, I think the essay a laborious and careful piece of work. The connection of the parts is well thought out, and the difficulties are not shirked. If there is little distinction about the thought or the expression distinction was perhaps hardly to be looked for in a work of simple exposition. I can draw no negative inference as to the powers of the author from this essay. And it does bear positive testimony, I think, to industry, exactitude, and general powers of mind much above the ordinary."

(Raleigh 1901)

The Bishop of Durham too makes a similar positive point towards the end of his report when he concludes: “... I think that the writer would be very likely to deal very effectively with a definite ethical subject” (Westcott 1901). Not withstanding the literary and theological criticism made against Pigou's essay, and the limited success that he had in identifying an ethical philosophy to underlie the body of Browning's poetry, it was this relationship between ethics and progress that held the strongest lessons for Pigou, so much so that they reveal a clear parallel with his subsequent work on wealth and welfare. Nowhere is this more significant than in the appendix to Robert Browning as a Religious Teacher, where Pigou draws attention to the following lesson from Browning:

"For the ordinary man who has anything to do with the government of a country, the ideal would be to 'do the best with the least change possible'. Every now and then, no doubt, a genius may arise, 'whose master-touch, not so much modifies, as makes anew'. The average man, however, is not made to revolutionize society, but rather to strive for a slow and gradual bettering of the conditions of human life. His method should be quiet and cautious, without admixture of subversive experiments.”

(Pigou 1901, p. 130)

This may suggest that Pigou developed some empathy for Browning in that the above statement reflects a non-dogmatic conservatism, but one that is fundamentally humanitarian: a view of human progress that re-emerges in Pigou's subsequent study of welfare, where quiet and cautious reflection on detail became his method for striving for the betterment of human life. Reflections on what is 'good' for the individual in Browning's poetry, namely when one succeeds in reconciling his or her self image with God's image for man, extend to a general view of what is 'good' for society, namely, the betterment of the conditions of human life. While not denying the possibility of genius, which renews and remakes rather than modifies, emerging every now and then, the general approach is not to place hopes too high on the emergence of such genius when bettering the conditions of human life.

\section{Assessments of Pigou's Successful Fellowship Thesis: The Causes and Effects of Changes in the Relative Values of Agricultural Produce in the United Kingdom during the last Fifty Years}

Pigou's second prize winning essay was also his second fellowship thesis. On this occasion, however, he dealt with the specific discipline subject that he was lecturing in - economics. But perhaps surprisingly, the original contribution of The Causes and Effects of Changes in the Relative Values of 
Agricultural Produce in the United Kingdom during the last Fifty Years did not lie in the treatment of economic theory. The theory presented in the thesis was fundamentally Marshallian. Rather, its contribution concerned the manner in which concepts associated with supply and demand theory were applied to the investigation of changes in agricultural commodity values over a fifty year period.

"It is impossible to mark off and claim as 'original' any part of an Essay of this kind. Certainly there is no originality about the main ideas at the back of it. I have learned them all from Professor Marshall's Principles of Economics, and have merely endeavoured to apply them to the particular problem of agriculture.”

(Pigou 1901b, pp. ii, italics added)

The result was an economic history. Of course, at the time Pigou was writing, agricultural prices were a very topical, as the effects of the Great Depression of the 1870s and 1880s was still within living memory. But, notwithstanding this, Pigou's study was not a traditional economic history. Rather, history was used as a means of demonstrating the relevance of partial equilibrium market analysis for the study of evolving changes in market conditions. Its main contribution was to demonstrate how theory can be applied to consider historical questions, including those from recent history.

To achieve that objective, he introduced the thesis with a rather technical discussion of the correct basis for comparing movement in the relative value of different agricultural commodities across periods of time. First, Pigou stressed the need to take account of variations in the value of money so that a 'real' notion of the changes in agricultural values could be considered. Second, Pigou outlined when it was permissible to use 'arithmetic' ratios to determine average prices for a period and when 'geometrics' ratios were needed for that purpose. For periods less than 12 months, Pigou argued that the practical effort in calculating annual averages using geometric ratios was not repaid by any significant improvement in the quality of calculations. For periods over one year, calculation of geometrically determined average prices were desirable to facilitate comparison without bias. In particular, when average values were considered over 5 year average periods and used for comparison with averages from other 5 year periods, Pigou regarded it as desirable to use geometric ratios. It is, as he said,

“important, when endeavouring to ascertain the changes that have taken place in relative values between, say, two quinquennial periods not to take arithmetic averages of the prices of commodities to be compared during the first five years and to compare the ratio between these averages with a ratio similarly calculated for the next quinquennium. The danger can be eliminated by taking geometrical instead of the arithmetic average.”

(Pigou 1901b p.7-8)

Pigou then dedicated the first formal chapter of the thesis to the presentation of an overview of the nature of markets. Given the significant historical dimension to his study, considerable attention was directed to the 'complicated interactions' between supply and demand. This was necessary because, having identified real relative price movements for a number of agricultural commodities, he worked backwards to isolate the general changes in supply and demand schedules for particular products with the aid of historical information concerning issues like changes in production technologies and tastes. Consequently, the role of the 'other things being equal assumption' in market analysis was discussed, as was its limitations for long-period analysis. When long-period changes were being considered, Pigou effectively removed the 'other things being equal' assumption on a sequenced and selective basis to highlight the interaction between supply and demand associated with a specific, but important, historical circumstance. For example, Pigou noted that a temporary change in supply, 
such as a decrease in price following a sudden increase in output of a particular agricultural good, may motivate changes in the demand for goods:

"When a chance increase in production brings value down temporarily, the result may be to accustom new people to the commodity in question and thus to elevate the curve of demand throughout that part of its course which lies to the left of the new consumption point."

(Pigou 1901b, p. 20)

In the same chapter Pigou also discussed some fundamentals of demand analysis, such as the concept of elasticity of demand. There is also some contextual discussion on the distributional impact of economic prosperity, with the benefits from such prosperity differing over time and among different social classes. Prior to 1873, Pigou considered the rich to be the main beneficiaries of prosperity, which had implications for the pattern of demand, whereas subsequent to that the benefits from prosperity were not only more significant, they were also more equally shared among all classes and with the benefits growing faster than in the earlier period. That too had implications for the pattern of demand.

Having laid the technical foundation for discussion of price movements and outlined a basic Marshallian theoretical perspective from which the causes and effects of these real price and quantity movements would be considered, Pigou then dedicated the majority of the thesis to applying these technical and theoretical perspectives to the study of movements in the value of various grains, such as wheat, barely, oats and fodder grains, and movements in the value of various meats and livestock products. In relation to quantity factors associated with supply to a particular market, Pigou pointed to differential impacts from: the relationship between foreign trade, foreign production and changes in shipping costs; the extended irrigation for American and Indian agricultural produce; changes in domestic transportation technology, such as the emerging railways and introduction of bulk carriages for wheat; the introduction of agricultural machines, such as the steam-going plough in 1870 and the harvester 1872; changes in disease among foreign animal stocks and the consequences for domestic meat supplies; and the emergence of technology that allowed frozen meat to be imported from colonies like Australia and New Zealand. There was also considerable discussion of the effects of lags between the decision to invest in agricultural product and the period required to bring that product to market. In relation to factors that affect the demand for agricultural products, Pigou pointed to: changes in the general prosperity of the period, which may cause the demand schedule for particular agricultural commodities to rise or fall; the availability of alternative agricultural commodities; and the relative price elasticity of demand for various agricultural commodities.

The influence of interdependence between supply and demand was also discussed on many occasions, with the source of new 'fashions' sometimes linked to changes in the conditions of supply. For example, from 1880 onwards, Pigou puzzled over why the relative price of oats grew faster than barley and concluded that this was due to the increasing popularity of oats for breakfast in the form of porridge. He then speculated that this may be a result of improvements in the quality of English milk, with the Government taking action to destroy unsanitary urban cow-sheds from 1870 following passage of the Food and Drugs Adulteration Act. Alternatively, changes in tastes were simply recognised, with the source of that change in fashion left unconsidered. Take wool for example, which was so important to the Australian economy in the period considered:

“in the later 70's English grown wool has experienced a depression particular to itself under the influence of a complete and sudden change of fashion in favour of soft merino wool, which greatly lowered the demand for the long-combing Lincoln wools”.

(Pigou 1901b, p.68). 
Moreover, as a large part of the cost of Australian wool comprised freight and carrying costs, which were diminishing for the general transport industry, and even more so in the specialised wool trade, Pigou pointed out that the period in Britain between 1870 and 1890 saw a considerable rise in dairy production relative to that of wool.

The thesis deals extensively with commodity issues that are important to a comprehensive economic history, but Pigou's fundamental purpose was to illustrate that partial equilibrium theory is powerful enough to bring additional insight to the operation of particular markets over long periods of time. That is, it was firstly an application of theory to reveal the versatility and relevance of that theory and secondly an economic history of agricultural commodity markets. Interestingly, the two assessors of the thesis saw its merits and faults in very different terms. Marshall, whose theory was being given extensive application, commenced his report with the words: "This thesis appears to me to be of exceptional excellence." Foxwell, however, was highly critical of the thesis, regarding many findings as trivial and others as too abstractly derived. Nevertheless, he still supported Pigou being elected as a fellow because "the paper is mainly of interest as an indication of the qualities of the author. These are in some respects remarkable”.

Marshall emphasised the difficulty of the questions that Pigou had addressed and the strength and originality that he brought to bear on these problems. He found that the distinctive feature of Pigou's study was "the coverage and success with which he has applied ... [general] principles in unravelling the intricately interwoven effects of the numerous causes affecting the values of agricultural products”. In the end:

"Pigou has I think been able to interpret completely the broader movements of the markets for wheat and some leading products; and the use which he has made of his knowledge seems to me masterly."

(Marshall 1901b)

Of course, Marshall's report is not devoid of criticism: he points to weakness in the discussion of small unorganised minor markets and the lack of any 'special access' to secrets that only merchants would have. But these are dismissed as minor complaints that detract little from the study. Moreover he finished his report by extensively quoting from the introduction to a letter he received from Langford Lowell Price, a former student of Marshall at Oxford and fellow of Oriel College Oxford (Koot and Rashid 1996, pp. 634-5), who had read Pigou's thesis when judging for the Cobden Prize.

"It seems to me to show a very remarkable capacity for economic argument; a firm mastery of abstract reasoning, which rarely, if ever, fails at exactness; and a complete command of a wide range of information. I have been fairly amazed at the ability with which a multitude of complex considerations is kept throughout in order ... The whole essay seems to me to afford conclusive evidence of high economic talent, and even of that originality which the author himself modestly does not claim”.

(Price, cited in Marshall 1901b)

Price mainly taught economic history and the history of economic thought at Oxford and was very supportive of a Marshallian mix of theory with history, ${ }^{11}$ and in this case it appears that he

\footnotetext{
${ }^{11}$ Koot and Rashid (1996, pp. 636) note that Price had defended Marshall's views on theory and history against criticisms raised by William Cunningham.
} 
regarded Pigou's blend of abstract reasoning and history as falling within that general approach. ${ }^{12}$ But the second examiner, Foxwell, did not share the same enthusiasm for Pigou's blending of abstract reasoning and history: "I should say at the outset that I cannot altogether approve of the general method of treatment adopted by the writer” (Foxwell 1902). His resulting criticisms are strong, as the following examples illustrate:

"As it [the thesis] arrives at no general conclusion, and does not seem to have been undertaken with any definite purpose in view, it lacks dramatic unity, and this strengthens a certain impression of sketchiness which it leaves on the reader.”

"Although he has made a wide survey of the facts, they seem to interest him mainly as illustrations of theory; and the paper is rather a study in conjecture than documented history. He is too much of a Ricardian; too much enamoured of his technical apparatus.”

"In Chapter II, section 2, six sheets of elaborate reasoning are devoted to the explanation of a variation in the relative value of barley and oats, as between 25 year periods; amounting to less than 2 per cent. It seems to me idle to apply complicated chains of probable reasoning to account for such insignificant changes.” ${ }^{13}$

“Generally I find an unnecessary obtrusion of technical terms, where the matter could be quiet clearly stated in ordinary language.”

(Foxwell 1902)

But Foxwell's comments were not entirely critical. He regarded Pigou's manner of writing as a "model of what a scientific style should be". While "there is nothing in the paper that strikes me as distinctly original", Foxwell (1902) went on to note that he detected an "ingenuity in the search for possible causes, and an alertness in the avoidance of plausible but unfounded conclusions, that seem to me quite exceptional, and to amount to a kind of genius”. In short then, it was the nuances of Pigou's literary exposition of matters related to economic history, and not his application of theoretical and technical apparatus to the history of agricultural commodities, that lead Foxwell to side in favour of Pigou's fellowship application.

However, before taking Foxwell's report on face value, it is necessary to consider whether it was influenced by non-scientific considerations, such as his relationship with Pigou. In that regard, it should be noted that Foxwell wrote to the Provost, on 17 October 1901, declining the initial invitation to examine the thesis.

\footnotetext{
${ }^{12}$ However, within a few years Price was critical of Pigou for his 'almost filial' respect for Marshall's utterances (Koot and Rashid 1996, pp. 638).

${ }^{13}$ On this point, Foxwell evidently drew on some of the data reported in Appendix A to Pigou's thesis, which shows ratios, multiplied by 100, of geometric price averages in one period to the previous period, except in the initial period when the relative price ratio is simply set at 100. Using a 25 year benchmark period for comparison, Pigou (1901b, Appendix, p.2) reports the following:

$\begin{array}{lrc}\text { Period } & \text { Barley } & \text { Oats } \\ 1850-1874 & 100.0 & 100.0 \\ 1874-1899 & 82.7 & 84.2\end{array}$

But Foxwell ignores the remaining data on barely and oats presented in the same appendix, which uses 10 year and 5 year comparative benchmarks. Those results show variations in the relative prices of these two commodities and serve as adequate motivation for Pigou's analysis of barely and oats. Furthermore, when arithmetic price averages are reported for these same commodities, as they are in Appendix B using a 5 year benchmark for comparison, the variations in relative prices are largely, and illegitimately, eliminated, underscoring Pigou's case for focusing on geometric price averages.
} 
"I should have been very willing to report upon Pigou's dissertation, the subject of which has a special interest for me: but we have recently been drawn into a somewhat antagonistic position as lecturers, and I am afraid this rather disqualifies me for the always delicate work of acting as referee in a fellowship competition.”

(Foxwell 1901)

Marshall had appointed Pigou to take his “General Course’ in economics for the Moral Sciences Tripos in 1901 when Pigou's earlier thesis on Browning was being evaluated. This had been agreed to by the Moral Sciences Board, but it was an action that was not received favourably by Foxwell, who had pronounced "Pigou a Prig, who, moreover, was unqualified to teach an elementary course" (Kadish 1989, 193). Marshall described the event in his letter of 22 May 1901 to John Neville Keynes:

"he [Foxwell] instantly cuts in before Pigou and duplicates in anticipation a part of the course which he knows the Mo. Sc. Board accepted with hearty approval a year ago and which Pigou was been preparing to give.

Of course, they will not really duplicate one another. Pigou could not duplicate him; and he has never done what I hope Pigou will ultimately do.

Pigou and I care for men: and I think I can truly say for men only. ${ }^{14}$ Foxwell does not seem to be able to understand this sort of aim, and hunts for some other"

(Marshall, cited in Kadish 1989, p. 194)

The bias in Foxwell's assessments is easily detected: he simply could not resist the temptation to assess the thesis in terms of a disciplined economic history. He acknowledged that it cannot be seen in those terms alone, but largely proceed to critically assess it on that basis. However, in view of the praise he bestowed on Pigou for his writing style and the almost 'genius' like manner that he avoided unfounded conclusions, it is likely that he managed to complete his assessment without malice.

But Marshall's assessment of Pigou's thesis was also biased, though in a very different way. Marshall's report of the thesis appears to be coloured by his knowledge of the man and his potential. Marshall's feelings for "what I hope Pigou will ultimately do" and his recognition that Pigou cared for men intruded on his assessment of the work under review. From this author's reading of the thesis, Marshall's reported views could not have been derived from consideration of the thesis alone: statements like, "this thesis appears to me to be of exceptional excellence" significantly overstate its scholarly qualities. Indeed, the proposition that Marshall's assessment of the thesis implicitly reports on Pigou the man and his potential as much as it explicitly reports on the thesis under review is corroborated somewhat by Marshall's reply to the Provost on 8 March 1901, which was sent in relation to Pigou's earlier unsuccessful fellowship thesis:

"In answer to your letter, I have great pleasure in saying that I have a very high opinion of the ability and character of A. C. Pigou. He seems to me to combine in a rare degree a patient and careful study of facts with vigorous constructive thought as to their mutual relations. He has a hearty, but well-balanced zeal for humanity. And this, combined with his eagerness and power in attacking hard problems, gives promise of exceptional energy and success in that realistic but thoughtful examination of the past and present, by which

\footnotetext{
${ }^{14}$ Given the claims of Pigou's misogyny, and the misogyny in Cambridge of the day more generally (Aslanbeigui 1997), it is uncertain whether Marshall's reference here to 'men' extends to both genders. Indeed, Chapter 14 of A Soaring Eagle (Groenewegen 1995) lends weight to the view that the reference did not extend to women, at least not if it involved extended participation in important economic and social institutions to women.
} 
alone we can get good guidance for the future in great matters. In economics the work of youth is so different in character from that of mature age, that one cannot securely predict the future: but my hopes as to what he will achieve for economics and for social wellbeing are as high as they well can be. ... With perhaps one exception, I have never wished so strongly to see any student retained at Cambridge, as Pigou."

(Marshall 1901a - italics added)

\section{Conclusions}

A year after his election to fellowship at King's College, 'Some Remarks on Utility’ (Pigou 1903) was published in the Economic Journal. Among other things, that article stressed that 'psychological hedonism' is an 'untenable and exploded doctrine', citing the Henry Sidgwick and T. H. Green and for authority on the matter. Sidgwick had turned to Jeremy Bentham and J. S. Mill for inspiration when reflecting on his utilitarian themes, differentiated utilitarianism from egoism as bases for moral judgement (Backhouse and Nishizawa 2010, p. 11). In contrast, Green, who turned to Kant and Hegel for inspiration during his reflections on idealism (Backhouse and Nishizawa 2010, p. 11), considered deliberation an important element of perfection or self realisation and he rejected hedonistic utilitarianism for its failure to recognise that moral agents deliberate on their desires and that an individual regulates his or her actions in light of such deliberations (Shionoya 2010, p. 99). To Pigou, the pertinent common feature of these diverse assessments was that "we do not desire only pleasure, but numerous other things as well” (Pigou 1903 [2002], p.21). ${ }^{15}$ In short, he was recognising that ethics and philosophical motivation often lay behind economic action. The multiplicity of sources that inspire human action are also a feature of poetic verse that deals with the human state. Prima facie, Pigou's first fellowship thesis appears somewhat incongruous for a scholar about to embark on an academic career in economics, but, as Pigou's thoughts moved from the notion of utility to the broader concept of welfare, including the relationship between 'economic' and 'total' welfare, the boundary between ethics, economics and even philosophic analysis of poetry become porous and less well defined.

In the first paragraph of Wealth and Welfare, he emphasised that welfare is concerned with what is good and is considered relative to states of consciousness:

Welfare means the same thing as good. It, too, cannot be defined, in the sense of being analysed. At the same time we can say, and, indeed, it is the chief task of ethics to say, whether, and in what way, particular things belong to welfare. ... welfare includes states of consciousness only, and not material things or conditions.

(Pigou 1912: 3)

Robert Browning as a Religious Teacher may be regarded as a philosophic study of 'states of consciousness' expressed through poetic verse, with emphasis placed on ethical considerations pertaining to the relationship between actions, consciousness and what is good for the individual and society. The assessors of this thesis recognised its 'exactitude' and the 'laborious', 'careful' and 'clearly expounded' manner in which the arguments were presented, but they also found fault with the imposed analytical rigidity and with Pigou's failure to give suitable prominence to an overall poetic or religious theme. But similar observations could also be made in reference to his early and important articles in welfare economics. This may be illustrated with reference to 'Producers' and Consumers'

\footnotetext{
${ }^{15}$ Acceptance of this view culminated in Pigou (temporarily) adopting Pareto's notion of 'ophelimity' in welfare studies (see McLure 2010).
} 
Surplus' (Pigou 1910), which introduced and formalised what we now refer to as externalities, for both the demand and supply sides of market relationships. Modern readers of this article may well be struck first by the careful discussion of sequences of fine conceptual and theoretical detail and the careful textually framed analytical demonstrations of such points. Given the advantage of hindsight, the major and enduring themes of the substantive general contribution of that paper are well known, but they only present to the reader after careful study of the theory and detail that Pigou presents. That approach has worked well for economic exposition, but the reception accorded to Pigou's first fellowship thesis 'appears' to suggest that scholars schooled in literary criticism are less likely to find that approach satisfactory: ${ }^{16}$ what was 'vice' for literary criticism became 'virtue' for economic analysis.

The final point to note on Pigou's first thesis is that that it represented a point in Pigou's intellectual development that had echoes of a similar event that took place in the early stages of Marshall's intellectual development. Specifically, as Simon Cook (2008, p. 26) has reported, in the late 1860s Marshall composed a dialogue entitled Poetry, which considered the merits of 'Browning against Tennyson' and found in favour of Browning's more realistic, and less romantic, approach to poetry. From his reading, Cook concluded that "for the young Marshall at least, good poetry was an objective exploration of character that did not transgress metaphysical boundaries and yet rested upon, and included within its scope, sound metaphysical insight” (2008, p. 27). Pigou, like Marshall, was also interested in both the exploration of character and the sound metaphysical insight revealed in Browning's poetry.

The reaction to Pigou's second thesis reveals some division of opinion within Cambridge over the relevance of Marshallian economics for economic history, with Marshall himself enthusiastically supportive of Pigou's approach to the history of agricultural commodities and Foxwell openly opposed to it. This thesis was not subsequently published and, while it is a scholarly and serious work, Foxwell's criticisms were not without substance. That is, when judged by the standards of economic history, deficiencies in the thesis are evident. But of course the thesis cannot just, or even primarily, be judged by the criteria of economic history, and, in that respect, Foxwell did not come to fully appreciate the merit of Pigou's study. But nor did the thesis warrant the fulsome praise that Marshall lavished upon it, even when it is primarily considered as a historical illustration of the power of partial equilibrium economics. No doubt Marshall was pleased to see his economic theory given application to the history of agricultural commodities, but his report also appears to be influenced by the student's and the master's shared view that economics may assist in determining what is good for society. From his letters it is clear that Marshall recognised that Pigou cared for 'men', but there is comparatively limited evidence of that care in the thesis under review. But of course Marshall's understanding of Pigou's wider motivations and general intellectual capabilities was very perceptive - indeed, he judged Pigou the scholar more accurately than the particular theses of Pigou that he assessed - and his expectations were largely realised in a short period of time: Pigou did care for 'men' and within a decade of obtaining his fellowship published what, with the advantage of hindsight, were seminal articles on welfare economics in the Economic Journal (Pigou 1903, 1904b, 1910) and a landmark study on Wealth and Welfare (1912) that went a considerable way to achieving what Marshall had hoped Pigou would achieve. ${ }^{17}$

\footnotetext{
${ }^{16}$ The word 'appears' has been used in the above sentence because the author is not schooled in literary criticism. Also, there are some dissenting voices on the merits of Pigou's writing style on economics matters. Gerhard Michael Ambrosi suggested to the author that when Pigou treats economic topics he often moves around in all sorts of side issues, leaving readers with a lack of orientation. Even Marshall had objected to Pigou phraseology employed to discuss cost curves (Bharadwaj 1972, p.42), which may well support Ambrosi's point over orientation of textual argument. Nevertheless, it appears that Pigou's desire to tease out and analyze the many and varied detailed elements of a problem helped in the development of a mode of thought that enhanced his creativity, which culminated in an increased profoundness that extended across his overall body of work.

${ }^{17}$ However, it should be noted that Marshall was not entirely uncritical of this book, as discussed in Bharadwaj (1972).
} 
Foxwell and Pigou, and others, came into direct competition again in 1908, this time for the chair in political economy at Cambridge following Marshall's retirement. As is well known, Marshall was active in the background lobbying for Pigou over Foxwell for that position (Aslanbeigui 1992 and Groenewegen 1995, p. 622-633; 676-677) and Pigou was elected as Marshall's successor. It is now evident that at least part of the motivation for Marshall's opposition to Foxwell had its origins in the period of Pigou's fellowship applications at King's college. First, Foxwell's reaction to Pigou taking over Marshall's general economics course served to establish, in Marshall's mind, that Foxwell would not place adequate emphasis on an ethically based foundation for a practically oriented economics. Second, Foxwell's criticisms of Pigou's thesis suggest a diminished view of the importance of economic theory for the explanation of concrete economic phenomena, relative to the position taken by Marshall. Pigou, in contrast, had revealed his inclination, and a growing capacity, to develop economic theory that linked to concrete economic phenomena along the lines envisaged by Marshall, eventually becoming Marshall's preferred candidate as his successor.

But perhaps the most curious feature of Pigou's successful thesis was that it suggested comparatively little about the future direction of his own studies in economics. It certainly served as a practical demonstration to Pigou of the analytical potential of partial equilibrium theory, and his application of that approach in the thesis to the study of agricultural commodities would have implicitly informed his early study on the taxation of corn (Pigou 1902b). However, the original elements of his subsequent and iconic works on welfare drew on his understanding of 'states of consciousness', which were more in evidence in his first thesis on Browning than in his second thesis on agricultural commodities. Of course, this does not suggest that the second thesis was devoid of any influence on his subsequent views on welfare: the discussion on prosperity and the distribution of benefits that accrue to the richer and poorer classes is entirely consistent with the discussion of material welfare improvements in Wealth and Welfare. Moreover, only the second thesis was built on the foundations of Marshallian theory, which were also important in the subsequent development of Pigou's welfare economics. But notwithstanding these factors, Pigou's reflections on states of consciousness and the conceptual notion of welfare had more to do with philosophy, by scholars such as Green and Sidgwick, and his own philosophical reflections of Browning's poetry, than with his analysis in the second, and successful, thesis on movements in relative agricultural values over the second half of the nineteenth century.

\section{References}

Aslanbeigui, Nahid 1992. 'Foxwell's Aims and Pigou's Military Service: A Malicious Episode?', Journal of the History of Economic Thought, 14(1), pp. 96-109

Aslanbeigui, Nahid 1997. 'Rethinking Pigou’s Misogyny’, Eastern Economic Journal, 23(3), pp. 301316

Bharadwaj, Krishna 1972. Marshall on Pigou's Wealth and Welfare. Economica, 39(153), pp. 32-46.

Backhouse, Roger E. and Nishizawa, Tamotsu (eds) 2010. No Wealth but Life: Welfare Economics and the Welfare State in Britain, 1880-1945, Cambridge: Cambridge University Press

Browning, Oscar 1910. Memories of Sixty Years at Eton, Cambridge and Elsewhere, Biblio Life, LLC

Cambridge University 1901. Cambridge University Calendar for the Year 1901-02, Cambridge: Deighton Bell.

Cook, Simon 2008. 'Poetry, Faith and Chivalry: Alfred Marshall's Response to Modern Socialism', History of Economics Review, 47, pp. 20-38.

Corrie, D. W. 1960. Unpublished letters, King's College Archive Centre: ACP1/Corrie 
Foxwell, H. S 1901.Unpublished letter to the Provost, King's College Archive Centre: Coll. 42 1902/Pigou.

Foxwell, H. S. 1902. Enclosed Report on A. C. Pigou's Dissertation, King's College Archive Centre: Coll. 42 1902/Pigou.

Gray, Edwin F. 1903. 'The New Economics Tripos at Cambridge University', Quarterly Journal of Economics, 17(3), pp .492-496.

Groenewegen, Peter, 1995. A Soaring Eagle: Alfred Marshal 1842-1924, Aldershot and Brookfield: Edward Elgar

Johnson, Harry 1960. 'Arthur Cecil Pigou', Canadian Journal of Economics and Political Science, 26(1), pp. 150-5.

Koot, Gerard M. and Rashid, Salim 1996. 'L.L. Price: Memories and Notes of an Oxford Economist', History of Political Economy, 28(4), pp. 633-640.

Kadish, Alon 1989. Historians, Economists and Economic History, London: Routledge.

Marshall, Alfred 1890 [1961]. Principles of Economics London: Macmillan

Marshall, Alfred 1901․ Unpublished letter to the Provost, Kings College Archive Centre, Coll.42:

Fellowship Election - 1901 A.C. Pigou.

Marshall, Alfred 1901b. A. C. Pigou’s Thesis, King’s College Archive Centre: Coll. 42 1902/Pigou.

McLure, Michael 2010. Pareto, Pigou and Third-party Consumption: Divergent Approaches to Welfare Theory with Implications for the Study of Public Finance, European Journal of the History of Economic Thought, (forthcoming).

Pigou, Arthur Cecil 1897-1899. Unpublished letters to Oscar Browning, King's College Archive Centre: $O B / 1 / 1281 / A$. $O B / 1 / 1281 / A$.

1899-1900. Unpublished letter to Oscar Browning, King's College Archive Centre:

1901a. Robert Browning as a Religious Teacher: Being the Burney Essay for 1900, London: C. J. Clay and Sons.

circa 1900-1901. Unpublished letter to Oscar Browning, King's College Archive Centre: OB/1/1281/A.

1901b. The Causes and Effects of Changes in the Relative Values of Agricultural Produce in the United Kingdom during the Last Fifty Years, King's College Archive Centre: Coll. KCAC/4/11/1/Pigou.

1902a A Parallel between Economic and Political Theory, Economic Journal, reprinted in A.C. Pigou Journal Articles 1902-1922, David Collard (ed.), 2002, Basingstoke: Palgrave Macmillan, pp. 1-4.

1902b A Point of Theory connected with the Corn Tax, Economic Journal, reprinted in A.C. Pigou Journal Articles 1902-1922, David Collard (ed.), 2002, Basingstoke: Palgrave Macmillan, pp. 5-11.

1903. Some Remarks on Utility. Economic Journal, reprinted in A.C. Pigou Journal Articles 1902-1922, David Collard (ed.), 2002, Basingstoke: Palgrave Macmillan, pp 12-22.

1904a. Pure Theory and the Fiscal Controversy. Economic Journal, reprinted in A.C. Pigou Journal Articles 1902-1922, David Collard (ed.), 2002, Basingstoke: Palgrave Macmillan, pp 29-33.

1904b. Monopoly and Consumers' Surplus. Economic Journal, reprinted in A.C. Pigou Journal Articles 1902-1922, David Collard (ed.), 2002, Basingstoke: Palgrave Macmillan, pp 30-37.

1905. Principles and Methods of Industrial Peace, London: Macmillan. 1906a. Protective and Preferential Import Duties, London: Macmillan. 
1906b. The Unity of Political and Economic Science. Economic Journal, reprinted in A.C. Pigou Journal Articles 1902-1922, David Collard (ed.), 2002, Basingstoke: Palgrave Macmillan, pp 86-94.

1906c. Protection and the Working Classes, Edinburgh Review, reprinted in A.C. Pigou Journal Articles 1902-1922, David Collard (ed.), 2002, Basingstoke: Palgrave Macmillan, pp 95126.

1907a. The Incidence of Import Duties. Economic Journal, reprinted in A.C. Pigou Journal Articles 1902-1922, David Collard (ed.), 2002, Basingstoke: Palgrave Macmillan, pp 127-132

1907b. Social Improvement in the Light of Modern Biology. Economic Journal, reprinted in A.C. Pigou Journal Articles 1902-1922, David Collard (ed.), 2002, Basingstoke: Palgrave Macmillan, pp 133-144.

1908. The Problems of Theism, London: Macmillan.

1910. Producers' and Consumers' Surplus. Economic Journal, reprinted in A.C. Pigou Journal Articles 1902-1922, David Collard (ed.), 2002, Basingstoke: Palgrave Macmillan, pp 165-177.

1912. Wealth and Welfare, London: Macmillan.

1932 [1946]. The Economics of Welfare, Fourth edition. London: Macmillan [earlier editions: 1920 first edition, 1924 second edition and1929 third edition]

Whitaker, John K. 1996. The Correspondence of Alfred Marshall, Economist, Volume two, At the Summit: 1891-1902, Cambridge: Cambridge University Press

Raleigh, Walter Alexander 1901. Report of Professor Raleigh, Kings College Archive Centre, Coll.42: Fellowship Election - 1901 A.C. Pigou

Saltmarsh, John and Wilkinson, Lancelot Patrick 1960. Arthur Cecil Pigou, 1877-1959, Cambridge: Cambridge University Press.

Shionoya, Yuichi 2010. 'The Oxford Approach to the Philosophical Foundations of the Welfare State', in No Wealth but Life: Welfare Economics and the Welfare State in Britain, 1880-1945, edited by Roger E. Backhouse and Tamotsu Nishizawa, Cambridge: Cambridge University Press, pp. 91113

Westcott, Brooke Foss 1901. Report of the Bishop of Durham, Kings College Archive Centre, Coll.42: Fellowship Election - 1901 A.C. Pigou 


\begin{tabular}{|c|c|c|}
\hline \multicolumn{3}{|c|}{$\begin{array}{c}\text { ECONOMICS DISCUSSION PAPERS } \\
2009\end{array}$} \\
\hline $\begin{array}{l}\text { DP } \\
\text { NUMBER }\end{array}$ & AUTHORS & TITLE \\
\hline 09.01 & Le, A.T. & $\begin{array}{l}\text { ENTRY INTO UNIVERSITY: ARE THE CHILDREN OF } \\
\text { IMMIGRANTS DISADVANTAGED? }\end{array}$ \\
\hline 09.02 & Wu, Y. & CHINA'S CAPITAL STOCK SERIES BY REGION AND SECTOR \\
\hline 09.03 & Chen, M.H. & $\begin{array}{l}\text { UNDERSTANDING WORLD COMMODITY PRICES RETURNS, } \\
\text { VOLATILITY AND DIVERSIFACATION }\end{array}$ \\
\hline 09.04 & Velagic, R. & UWA DISCUSSION PAPERS IN ECONOMICS: THE FIRST 650 \\
\hline 09.05 & McLure, M. & $\begin{array}{l}\text { ROYALTIES FOR REGIONS: ACCOUNTABILITY AND } \\
\text { SUSTAINABILITY }\end{array}$ \\
\hline 09.06 & Chen, A. and Groenewold, N. & $\begin{array}{l}\text { REDUCING REGIONAL DISPARITIES IN CHINA: AN } \\
\text { EVALUATION OF ALTERNATIVE POLICIES }\end{array}$ \\
\hline 09.07 & Groenewold, N. and Hagger, A. & $\begin{array}{l}\text { THE REGIONAL ECONOMIC EFFECTS OF IMMIGRATION: } \\
\text { SIMULATION RESULTS FROM A SMALL CGE MODEL. }\end{array}$ \\
\hline 09.08 & Clements, K. and Chen, D. & AFFLUENCE AND FOOD: SIMPLE WAY TO INFER INCOMES \\
\hline 09.09 & Clements, K. and Maesepp, M. & A SELF-REFLECTIVE INVERSE DEMAND SYSTEM \\
\hline 09.10 & Jones, C. & $\begin{array}{l}\text { MEASURING WESTERN AUSTRALIAN HOUSE PRICES: } \\
\text { METHODS AND IMPLICATIONS }\end{array}$ \\
\hline 09.11 & Siddique, M.A.B. & $\begin{array}{l}\text { WESTERN AUSTRALIA-JAPAN MINING CO-OPERATION: AN } \\
\text { HISTORICAL OVERVIEW }\end{array}$ \\
\hline 09.12 & Weber, E.J. & $\begin{array}{l}\text { PRE-INDUSTRIAL BIMETALLISM: THE INDEX COIN } \\
\text { HYPTHESIS }\end{array}$ \\
\hline 09.13 & McLure, M. & $\begin{array}{l}\text { PARETO AND PIGOU ON OPHELIMITY, UTILITY AND } \\
\text { WELFARE: IMPLICATIONS FOR PUBLIC FINANCE }\end{array}$ \\
\hline 09.14 & Weber, E.J. & $\begin{array}{l}\text { WILFRED EDWARD GRAHAM SALTER: THE MERITS OF A } \\
\text { CLASSICAL ECONOMIC EDUCATION }\end{array}$ \\
\hline 09.15 & Tyers, R. and Huang, L. & $\begin{array}{l}\text { COMBATING CHINA'S EXPORT CONTRACTION: FISCAL } \\
\text { EXPANSION OR ACCELERATED INDUSTRIAL REFORM }\end{array}$ \\
\hline 09.16 & $\begin{array}{l}\text { Zweifel, P., Plaff, D. and } \\
\text { Kühn, J. }\end{array}$ & $\begin{array}{l}\text { IS REGULATING THE SOLVENCY OF BANKS COUNTER- } \\
\text { PRODUCTIVE? }\end{array}$ \\
\hline 09.17 & Clements, K. & THE PHD CONFERENCE REACHES ADULTHOOD \\
\hline 09.18 & McLure, M. & $\begin{array}{l}\text { THIRTY YEARS OF ECONOMICS: UWA AND THE WA } \\
\text { BRANCH OF THE ECONOMIC SOCIETY FROM } 1963 \text { TO } 1992\end{array}$ \\
\hline 09.19 & Harris, R.G. and Robertson, P. & $\begin{array}{l}\text { TRADE, WAGES AND SKILL ACCUMULATION IN THE } \\
\text { EMERGING GIANTS }\end{array}$ \\
\hline 09.20 & $\begin{array}{l}\text { Peng, J., Cui, J., Qin, F. and } \\
\text { Groenewold, N. }\end{array}$ & STOCK PRICES AND THE MACRO ECONOMY IN CHINA \\
\hline 09.21 & Chen, A. and Groenewold, N. & $\begin{array}{l}\text { REGIONAL EQUALITY AND NATIONAL DEVELOPMENT IN } \\
\text { CHINA: IS THERE A TRADE-OFF? }\end{array}$ \\
\hline
\end{tabular}




\begin{tabular}{|c|c|c|}
\hline \multicolumn{3}{|c|}{$\begin{array}{c}\text { ECONOMICS DISCUSSION PAPERS } \\
2010\end{array}$} \\
\hline $\begin{array}{l}\text { DP } \\
\text { NUMBER }\end{array}$ & AUTHORS & TITLE \\
\hline 10.01 & Hendry, D.F. & $\begin{array}{l}\text { RESEARCH AND THE ACADEMIC: A TALE OF } \\
\text { TWO CULTURES }\end{array}$ \\
\hline 10.02 & McLure, M., Turkington, D. and Weber, E.J. & A CONVERSATION WITH ARNOLD ZELLNER \\
\hline 10.03 & $\begin{array}{l}\text { Butler, D.J., Burbank, V.K. and } \\
\text { Chisholm, J.S. }\end{array}$ & $\begin{array}{l}\text { THE FRAMES BEHIND THE GAMES: PLAYER'S } \\
\text { PERCEPTIONS OF PRISONER'S DILEMMA, } \\
\text { CHICKEN, DICTATOR, AND ULTIMATUM GAMES }\end{array}$ \\
\hline 10.04 & Harris, R.G., Robertson, P.E. and Xu, J.Y. & $\begin{array}{l}\text { THE INTERNATIONAL EFFECTS OF CHINA'S } \\
\text { GROWTH, TRADE AND EDUCATION BOOMS }\end{array}$ \\
\hline 10.05 & Clements, K.W., Mongey, S. and Si, J. & $\begin{array}{l}\text { THE DYNAMICS OF NEW RESOURCE PROJECTS } \\
\text { A PROGRESS REPORT }\end{array}$ \\
\hline 10.06 & Costello, G., Fraser, P., Groenewold, N. & $\begin{array}{l}\text { HOUSE PRICES, NON-FUNDAMENTAL } \\
\text { COMPONENTS AND INTERSTATE SPILLOVERS: } \\
\text { THE AUSTRALIAN EXPERIENCE }\end{array}$ \\
\hline 10.07 & Clements, K. & $\begin{array}{l}\text { REPORT OF THE } 2009 \text { PHD CONFERENCE IN } \\
\text { ECONOMICS AND BUSINESS }\end{array}$ \\
\hline 10.08 & Robertson, P.E. & $\begin{array}{l}\text { INVESTMENT LED GROWTH IN INDIA: HINDU } \\
\text { FACT OR MYTHOLOGY? }\end{array}$ \\
\hline 10.09 & Fu, D., Wu, Y., Tang, Y. & $\begin{array}{l}\text { THE EFFECTS OF OWNERSHIP STRUCTURE AND } \\
\text { INDUSTRY CHARACTERISTICS ON EXPORT } \\
\text { PERFORMANCE }\end{array}$ \\
\hline 10.10 & $\mathrm{Wu}, \mathrm{Y}$. & $\begin{array}{l}\text { INNOVATION AND ECONOMIC GROWTH IN } \\
\text { CHINA }\end{array}$ \\
\hline 10.11 & Stephens, B.J. & $\begin{array}{l}\text { THE DETERMINANTS OF LABOUR FORCE } \\
\text { STATUS AMONG INDIGENOUS AUSTRALIANS }\end{array}$ \\
\hline 10.12 & Davies, $\mathrm{M}$. & $\begin{array}{l}\text { FINANCING THE BURRA BURRA MINES, SOUTH } \\
\text { AUSTRALIA: LIQUIDITY PROBLEMS AND } \\
\text { RESOLUTIONS }\end{array}$ \\
\hline 10.13 & Tyers, R., Zhang, Y. & APPRECIATING THE RENMINBI \\
\hline 10.14 & Clements, K.W., Lan, Y., Seah, S.P. & $\begin{array}{l}\text { THE BIG MAC INDEX TWO DECADES ON } \\
\text { AN EVALUATION OF BURGERNOMICS }\end{array}$ \\
\hline 10.15 & Robertson, P.E., Xu, J.Y. & $\begin{array}{l}\text { IN CHINA'S WAKE: } \\
\text { HAS ASIA GAINED FROM CHINA'S GROWTH? }\end{array}$ \\
\hline 10.16 & Clements, K.W., Izan, H.Y. & $\begin{array}{l}\text { THE PAY PARITY MATRIX: A TOOL FOR } \\
\text { ANALYSING THE STRUCTURE OF PAY }\end{array}$ \\
\hline 10.17 & Gao, G. & WORLD FOOD DEMAND \\
\hline 10.18 & Wu, Y. & $\begin{array}{l}\text { INDIGENOUS INNOVATION IN CHINA: } \\
\text { IMPLICATIONS FOR SUSTAINABLE GROWTH }\end{array}$ \\
\hline 10.19 & Robertson, P.E. & DECIPHERING THE HINDU GROWTH EPIC \\
\hline 10.20 & Stevens, G. & $\begin{array}{l}\text { RESERVE BANK OF AUSTRALIA-THE ROLE OF } \\
\text { FINANCE }\end{array}$ \\
\hline
\end{tabular}




\begin{tabular}{|l|l|l|}
\hline 10.21 & Widmer, P.K., Zweifel, P., Farsi, M. & $\begin{array}{l}\text { ACCOUNTING FOR HETEROGENEITY IN THE } \\
\text { MEASUREMENT OF HOSPITAL PERFORMANCE }\end{array}$ \\
\hline 10.22 & McLure, M. & $\begin{array}{l}\text { ASSESSMENTS OF A. C. PIGOU'S FELLOWSHIP } \\
\text { THESES }\end{array}$ \\
\hline 10.23 & Poon, A.R. & $\begin{array}{l}\text { THE ECONOMICS OF NONLINEAR PRICING: } \\
\text { EVIDENCE FROM AIRFARES AND GROCERY } \\
\text { PRICES }\end{array}$ \\
\hline 10.24 & Halperin, D. & $\begin{array}{l}\text { FORECASTING METALS RETURNS: A BAYESIAN } \\
\text { DECISION THEORETIC APPROACH }\end{array}$ \\
\hline 10.25 & Clements, K.W., Si. J. & $\begin{array}{l}\text { THE INVESTMENT PROJECT PIPELINE: COST } \\
\text { ESCALATION, LEAD-TIME, SUCCESS, FAILURE } \\
\text { AND SPEED }\end{array}$ \\
\hline 10.26 & $\begin{array}{l}\text { Chen, A., Groenewold, N., } \\
\text { Hagger, A.J. }\end{array}$ & $\begin{array}{l}\text { THE REGIONAL ECONOMIC EFFECTS OF A } \\
\text { REDUCTION IN CARBON EMISSIONS }\end{array}$ \\
\hline 10.27 & $\begin{array}{l}\text { Siddique, A., Selvanathan, E.A., } \\
\text { Selvanathan, S. }\end{array}$ & $\begin{array}{l}\text { REMITTANCES AND ECONOMIC GROWTH: } \\
\text { EMPIRICAL EVIDENCE FROM BANGLADESH, } \\
\text { INDIA AND SRI LANKA }\end{array}$ \\
\hline
\end{tabular}

